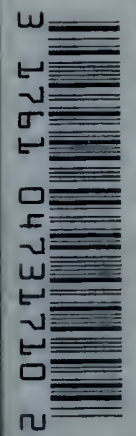

QR

58

L3 
Digitized by the Internet Archive in 2008 with funding from Microsoft Corporation 

, 




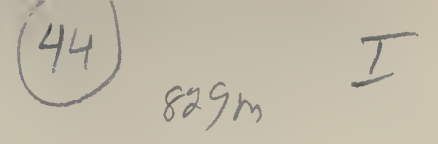

\section{THE HARVEIAN ORATION.}

1888 


\section{Cambrioge:}

PRINTED BY C. J. CLAS, M.A. AND SONS, AT THE UNIVERSITY PRESS. 


\section{THE}

\section{HARVEIAN ORATION}

DELIVERED BEFORE .

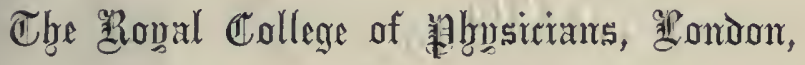

$$
\text { OCTOBER 18, } 1888 .
$$

\section{P. W. LATHAM, M.A., M.D.,}

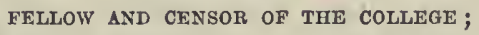

FELLOW AND CENSOR OF THE COLLEGE;

DOWNING PROFESSOR OF MEDICINE IN THE ONIVERSITY OF CAMBRIDGE; SENIOR PHYSICIAN TO ADDENBROOKE'S HOSPITAL.

CAMBRIDGE:

\section{DEIGHTON, BELL, AND CÓ}

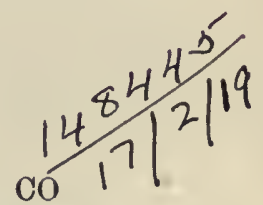

LONDON: GEORGE BELL AND SONS. 
$Q R$

58

13

W. 110

mann s: 


\section{SIR WILLIAM JENNER, BART., K.C.B.,}

M.D. LOND., D.C.L. OXON., LL.D. CANTAB. ET EDIN., F.R.S.,

FOR SEVEX YEARS

PRESIDENT OF THE ROYAL COLLEGE OF PHYSICIANS, PIYSICIAN IN ORDINARY TO HER MAJESTY THE QUEEN, AND TO IUIS ROYAL HIGHNESS THE PRINCE OF WALES,

\section{THIS ORATION}

DELIVERED BY HIS DESIRE

IS DEDICATED

WITII PROFOUND RESPECT AND ESTEEM. 



\section{THE HARVEIAN ORATION.}

\section{8.}

\section{Mr President and Gentlenen,}

To-day we meet together in fulfilment of the express wish of Harvey, our illustrious benefactor, and most distinguished ornament, and it is my duty "to commemorate the benefactors of the College and to encourage its members to search out the secrets of nature by way of experiment."

I will not apologise for endeavouring to perform this duty, imposed upon me by our past President, heartily though I wish it had fallen into worthier hands. As a duty I accepted the task; it is made a pleasant one by the feeling that, in commemorating the achievements of the past, I shall have the sympathy of my audience; and if by pointing to the direction in which further advances are possible, and suggesting routes by which these advances may be made, $\mathrm{I}$ can stimulate and encourage any here present to search out these secrets of nature, I shall feel that the very deep anxiety with which $I$ undertook to address you has not been altogether fruitless.

And what are the achievements of the past? and of the 
present? Is disease being prevented? Is life being prolonged? Is pain lessened? When disease arises can it be more skilfully treated or more rapidly controlled? It is almost superfluous for me in this assembly to answer these questions or to point out how intimately our progress has been associated with and dependent upon Harvey's great discovery. As illustrations, need I speak here of the diminished mortality from consumption, which, by the recognition of and attention to ordinary sanitary laws, has during the last quarter of a century been reduced in England and Wales 28 per cent.? or of the diminished mortality from ague or from typhoid fever? Is pain lessened? Need I refer to ether and chloroform, or to nitrite of amyl which is now finding a more extended use than in simply relieving angina pectoris; or to the hypodermic injections of remedies such as morphia and ether? When disease arises can it be more skilfully treated or more rapidly controlled? Need I speak of the effects of the bromides in epilepsy and allied disorders; of the specific effect of quinine in ague, or of the equally specific effect, in proper doses and with suitable diet, of the salicyl compounds in acute rheumatism; of the diminished mortality from pneumonia; of the use of the aspirator in pleuritic and pericardial effusions; of our increased skill in the localisation of cerebral disease and the brilliant results which are now achieved by surgery in connection therewith? All these are modern advances of which we may well be proud. The names of those, many of them happily still living among us, to whom we owe this increased knowledge, are known to you all. It is unnecessary therefore to commemorate singly those distinguished Fellows of this College whose names connected with the advance of medicine will be cherished by posterity not only as Benefactors of this College, but of mankind at large. 
And what shall I say of our greatest Benefactor whose memory we specially commemorate to-day? When I turn to the orations delivered by my predecessors, I find that the history of Harvey's life, his surroundings, his mode of investigating nature, his early studies, classical, dialectical, and physical, his habit of inductive reasoning, the steps leading to his great discovery, the grounds for asserting his rightful claim to be the discoverer, have all been so eloquently discussed and so exhaustively displayed before you, that it would be out of place for me to dilate on any of these themes. Permit me rather to picture before you to-day some of the discoveries which have been made in modern times, in matters connected with the circulation, and more particularly as regards some of the changes in the blood which may be associated with or productive of disease, and thus to indicate some of the additions to that fabric of scientific medicine of which Harvey's great discovery is the corner stone.

Following upon the labours of Harvey, we note the discovery of the capillaries by Malpighi, about 1687, our knowledge thereof improved by Leeuwenhoek in 1729 and then by Hales, Cowper, Haller and Lieberkïhn, and perfected by Prochaska in his publication in 1812. Subsequently we learned how the rhythm of the heart may be interfered with by causes acting through the nervous system, and how the calibre of the minute arteries may be modified through the same agency. Then we have the changes connected with inflammation; and can we not picture to ourselves with what special interest such an observer as Harvey would have watched the changes which take place in the vessels and the surrounding tissues following upon irritation or inflarnmation; and which, by the aid of those appliances with which modern science has furnished us, have been discovered in recent 
times? I refer to the dilatation and relaxed condition of the vessels, the slowing of the blood stream, the falling out of the colourless corpuscles, like tired soldiers on the march, as Professor Burdon Sanderson has expressed it, their leaving the midstream and loitering against the vein wall, afterwards sticking to it, and then in some wonderful way wandering out, emigrating through the unbroken vascular wall into the surrounding space, some of them becoming disintegrated and dissolved in the liquid which is also effused, and so leading to an accumulation of coagulable lymph or inflammatory exudation external to the vessels. How much is there in these phenomena which still requires investigation and explanation! Why do the bloodvessels dilate? how is the emigration of the colourless corpuscles to be explained? by what means also, do these corpuscles "penetrate into dead tissue and indeed into any material capable of imbibition with which they are brought into contact in an active state"? And then the further questions may be suggested: Does there exist an autagonism or attraction between these white corpuscles and those recently discovered organisms the bacilli? Is there a struggle for existence between them? How are the powers, and action, and growth of the colourless corpuscles modified by the presence of these micro-organisms? What part do the latter play in the production of disease? Is it true that a large part of all health and disease in the world is dependent upon them? Such questions as these indicate the degree of importance which must be assigned to the discovery of these bodies, and account for the interest in them which prevails at the present time. Probably no other discovery since that of the circulation of the blood appears to be so full of promise in elucidating the causes and courses of some diseases as this one. 
These micro-organisms in various forms seem to take part in the destructive changes, with which we are familiar in the animal and vegetable world, they are found in connection with certain diseases, and some of them have their home in the circulatory apparatus. Is it not then peculiarly fitting that on an occasion like this some reference should-be made to these micro-organisms? We can rightly commemorate and rejoice over the work which has been done in this direction, whilst we feel at the same time how much there is still unsettled and obscure. The knowledge gained from the experimental observations on animals is as yet applicable only within very narrow limits to the human subject. Nay more, the results of clinical observation are altogether inconsistent in many cases with what these experiments would suggest; and yet how fruitful and full of promise does the territory seem from our present stand-point! Is it not one to which I may point encouragingly and ask you to explore it, and bid you, in Harvey's words, "search out its secrets by way of experiment"?

Let me briefly remind you of some of the facts which have been made out regarding these bodies.

There can be little doubt that in some disorders these organisms in their various forms, round, corkscrew or straightrod shaped, are the causal connection, the virus, of the disease. The bacilli are constantly present in the affected parts, the organisms have been cultivated outside the body, and separated from all the morbid materials, and the disease has been produced by the introduction of these cultivated organisms into healthy animals. As examples of such disorders we have, as described by Koch, anthrax or splenic fever, a septicæmia in mice due to bacteria, and a septicemia in rabbits due to micrococci. An 
animal inoculated with the smallest drop of anthracic blood, provided it contains bacilli or their spores, dies within 24 or 36 hours-and then in the capillaries of the liver, spleen, lungs, kidneys and stomach incredible numbers of these bacilli can be seen permeating this portion of the vascular system, whilst in the larger vessels even in the arteries and veins of an intestinal villus they may be entirely absent or only seen at long intervals-and it is remarkable that in the capillaries of the brain, skin, muscle and tongue there are fewer than elsewhere. The development of such numbers in so short a time appears almost incredible. The bacillus subtilis however, which is not parasitic, but otherwise very much like bacillus anthracis in all respects, with a good supply of food and oxygen and a temperature of $30^{\circ} \mathrm{C} .\left(86^{\circ} \mathrm{F}.\right)$, doubles its length and divides once every thirty minutes, forming two separate organisms. By an easy calculation therefore, we find that at the end of twenty-four hours the progeny of such a bacillus increasing at such a rate, would amount to upwards of eight hundred millions of millions.

In anthrax it would seem to be quite clear, then, that the bacillus will give rise to the disorder. There can be little doubt also that woolsorters' disease, malignant pustule, and intestinal anthrax in the human subject are developed from the same source.

As an example of a disease connected with a spirillum or spirochæta we have that of relapsing fever; a disorder in the spread of which it is certain, that contagion from the sick or through the intervention of articles of daily use plays a very important part. During the febrile condition of the patient, a slender thread-like and twisted organism, which is never still, but always moving about in various directions, is found 
in great numbers in the blood-the Spirochæta Obermeiericlosely resembling the innocuous Spirochrta Cohnii or plicatilis found in the mucus of the teeth. During the intervals between the febrile attacks none of these organisms can be detected in the blood. Outside the body they show active movements at a temperature of $60^{\circ}$ or $70^{\circ}$, become languid at blood heat and die at fever heat. The pyrexia therefore of the patient is supposed to destroy the organism, which then breaks up into a number of minute granules, some of which may constitute the spores from which fresh crops of the organism may develope. If blood containing spirochætæ is taken from a patient during the stage of pyrexia and human beings or monkeys inoculated with it, the disease can be reproduced, but not by blood taken during the intervals between the febrile attacks. Injections of the blood into other animals such as dogs, rabbits and guinea-pigs were always without result. All attempts to cultivate the organism outside the body have as yet been unsuccessful, so that we really know very little of its history.

Here again we have a disorder associated with a bacillus, the organism disappearing and reappearing from the system and the blood of the infected animal being intermittent in its power of communicating the disease to other animals.

Perhaps few disorders of the human frame have greater interest attached to them than those associated with tubercle, and when we remember that one-seventh on an average of the deaths of human beings result from pulmonary tuberculosis, the importance of any fresh light shed on this disorder, or the discovery of any new fact can not easily be overestimated. The discovery, then, by Koch in 1882 of a bacillus in the tubercular diseases of man and animals has necessarily attracted a good deal of attention and led 
to a good deal of diseussion. These rod-shaped bacilli have been shown to exist, in all cases of human tuberculosis, in the sputum, in caseating scrofulous glands, and in the tubercular masses in the lungs. Pure eultivations of these baeilli when introduced beneath the skin of susceptible animals sueh as rabbits, guineapigs, cats, and field-mice, always produce after three, four, or more weeks, the typical tubercular lesions; swollen lymphatic glands, deposits in the spleen, liver, and lungs, and enlargement and easeation of the bronchial glands. Different species of animals present very different degrees of susceptibility; the domestic mouse is not easily affected, whereas the field-mouse is highly susceptible; and as every practical physieian knows, in certain families of the human species there is an unmistakable liability, an inborn tendency to suffer from tuberculosis, whereas other families entirely escape. Wherein lies this great difference of susceptibility? In what way do the miero-organisms either in tuberculosis or anthrax or relapsing-fever influence the economy? how do they produce the disease? Why should some animals resist their power and others be overwhelmed by them? Recent investigations seem to me to throw some light on these points, and in some degree to answer these questions.

When certain forms of bacilli, of the so-called non-pathogenic eharacter, are introduced into the blood of the lower animals, even in large numbers, their existence is of comparatively short duration, and they speedily disappear. The living blood has the power of destroying them. In thrce hours according to Wyssokowitsch none are present even though enormous numbers are injected. They are deposited in the liver, spleen, and medulla of bone, and soon die if they do not contain spores. If spores are injected these live much longer, those of bacillus subtilis being still 
alive after three months. But there is another way in which they are destroyed. "When bacteria are injected into the tissues there follows a struggle for existence between them and the cellular elements. Leucocytes quickly accumulate in the neighbourhood of the mass of bacteria, and then there follows a fight for the mastery between these cells and the bacteria. The cells take up the bacteria into their interior, and where the bacteria are nonpathogenic for the animal employed they are destroyed" (Cheyne). The discovery of this is due to Metschnikoff. It is well known that the colourless blood-cells possess the power of constantly changing their shape, exhibiting undulatory movements and alternate protrusion and retraction of processes; they are also able to take up and' absorb solid bodies into their soft substance. "If the foreign body comes into contact with the surface of the cell, the latter puts out processes which embrace it and gradually close over it as the waves close over a drowning animal, so that it lies at last inside the soft cell substance. It may be cast out again at some future time, but it may also suffer decomposition inside the cell, be killed and disappear." These well-known facts led Metschnikoff to investigate the behaviour of the colourless blood cells of the vertebrate animals towards the bacillus of anthrax. "He found that the virulent rods when introduced by inoculation into an animal liable to take the fever, such as a rodent, were not absorbed by the blood cells, or only in exceptional instances. They were readily absorbed by the blood-cells of animals not liable to the disease, as frogs and lizards, provided the temperature was not artificially raised, and then disappeared inside the cells. The same thing happened when susceptible animals were inoculated with bacillus anthracis which had been attenuated to the harmless state." Metschnikoff therefore assumed "that the bacillus 
is harmless because it is absorbed and destroyed by the bloodcells, and injurious because this does not happen; or at least that it becomes harmless if the destruction by the blood-cells takes place more rapidly and to a greater extent than the growth and multiplication of the bacillus, the converse being also true." If in the case of frogs, the temperature be raised, "thus favouring the growth of the bacilli and at the same time lowering the vitality of the cells, the bacilli grow and penetrate into the circulating blood."

If, however, the bacilli when introduced into the blood or into the tissues are not destroyed by the colourless blood-cells or otherwise, but are such as are able to live in the blood or tissues of living animals, what is the nature of the change which they produce? It appears that among the products which result from the decomposition of organised matter and are associated with the growth of bacteria, certain chemical poisons appear, which are capable of destroying animal life. We have long been familiar with the fact that the micrococcus or bacillus lacticus is the agent by which the lactic acid fermentation of the sugar contained in milk takes place, and that this lactic acid being neutralised with lime or other substance, will, after a time, through the agency of another micro-organism, probably the bacillus amylobacter, undergo a further change or fermentation, and be converted into butyric acid, with the simultaneous evolution of carbonic acid and hydrogen.

$$
2 \mathrm{C}_{2} \mathrm{H}_{4}\left\{\begin{array}{l}
\mathrm{OH} \\
\text { lactic acid }
\end{array}=\underset{\text { butyric acid }}{\mathrm{C}_{8} \mathrm{H}_{5} \cdot \mathrm{COOH}}+2 \mathrm{CO}_{2}+2 \mathrm{H}_{2} .\right.
$$

And there are other fermentations of a similar character. But it is only in recent times that it has been discovered that, as 
the result of albuminous or proteid decomposition or putrefaction, certain animal alkaloids are produced, similar in their nature and in their chemical composition to the regetable alkaloids. Some of these products, or ptomaines as they are called, are innocuous, others possess poisonous properties varying in degree from the slighter forms to the most intense activity. Nearly 70 years ago Kerner pointed out the similarity of the effects produced by sausage-poison to those produced by atropine, but the symptoms are slower in appearing-sometimes two, three, or four days may elapse before they manifest themselves. Dr Alfred Swaine Taylor mentions the fact that in 1859 sixty-four persons suffered from the poisonous effects of a certain batch of sausages, only one case however proving fatal. Chemical analysis of the sausages yielded nothing of a poisonous nature, though there could be no donbt that they had caused the symptoms and death. The symptoms were-burning in the throat and stomach, followed by vomiting and purging; giddiness and confusion in the head, and in some cases delirium.

It might now possibly be urged, with our present knowledge, that the symptoms arose from the formation of an animal alkaloid in the meat, developed through the agency of such an organism as Cohn's bacterium termo or Bienstock's drumstick bacillus.

From partial decay, through the agency of Tyrothrix tenuis or some other bacterium, cheese sometimes acquires irritant properties and will give rise to vomiting and purging more or less violent in those who have eaten it.

Pickled or tinned salmon, salted herrings and even fresh mussels, are examples of articles of diet which have caused poisonous symptoms in those who have partaken of them.

In 1856 Panum showed that these effects were the result of L. 
some chemical poison developed in putrefying material. He subjected the fluids to prolonged boiling so as to destroy any living organisms, and on injecting it into animals the poisonous effects were still produced though in a slighter form than from the unboiled fluid. Further, after filtering the fluid and boiling it for an hour he evaporated it to dryness, then digested it with absolute alcohol and treated the residue with boiling water. This watery extract also was poisonous. Some of these chemical substances or animal alkaloids were separated by Armand Gautier in 1872 and by Professor Selmi of Bologna and named by him ptomaines. Professor Brieger has since succeeded in producing these bodies, and some not poisonous, in a crystalline form, and in determining their chemical composition. The following are some of them :

Neuridin $\mathrm{C}_{5} \mathrm{H}_{14} \mathrm{~N}_{2}$, a non-poisonous alkaloid, is the one which is most constantly present at the commencement of putrefaction and which appears in largest quantity. This substance can be split up into dimethylamine and trimethylamine :-

$$
\underset{\text { neuridin }}{\mathrm{C}_{5} \mathrm{H}_{14} \mathrm{~N}_{2}}+\mathrm{H}_{3}=\underset{\text { dimethylamine trimethylamine. }}{\mathrm{NH}}\left(\mathrm{CH}_{3}\right)_{2}+\underset{\left.\mathrm{CH}_{3}\right)_{3}}{\mathrm{~N}\left(\mathrm{CH}_{3}\right.}
$$

After the removal of this from putrefying flesh two poisons can be extracted, neurin $\mathrm{C}_{8} \mathrm{H}_{13} \mathrm{NO}$ and cholin $\mathrm{C}_{5} \mathrm{H}_{15} \mathrm{NO}_{2}$, differing only in composition by a molecule of $\mathrm{H}_{2} \mathrm{O}$, but the neurin being ten times more poisonous than cholin; which latter exists normally in the bile, and as a constituent of lecithin in the brain, and in yolk of egg. From putrefying fish, and gelatine, muscarine $\mathrm{C}_{5} \mathrm{H}_{16} \mathrm{NO}_{3}$ is obtained; an alkaloid previously discovered by Schmiedeberg and Koppe, as the poisonous agent in a disease of flies caused by a fungus, the agaricus muscarius. Brieger also obtained other substances from deconposing albuminous substances and human corpses, viz. ethylene diamine $\mathrm{C}_{2} \mathrm{H}_{4}\left(\mathrm{NH}_{2}\right)_{2}$, gadinin $\mathrm{C}_{7} \mathrm{H}_{17} \mathrm{NO}_{2}$, 
trimethylamine $\mathrm{N}\left(\mathrm{CH}_{3}\right)_{3}$, dimethylamine $\mathrm{NH}\left(\mathrm{CH}_{3}\right)_{2}$ and triethylamine $\mathrm{N}\left(\mathrm{C}_{2} \mathrm{H}_{5}\right)_{3}$, cadaverin $\mathrm{C}_{5} \mathrm{H}_{16} \mathrm{~N}_{8}$, putrescin $\mathrm{C}_{4} \mathrm{H}_{12} \mathrm{~N}_{8}$, saprin $\mathrm{C}_{5} \mathrm{H}_{16} \mathrm{~N}_{2}$ and mydalein. The amount of these substances obtained depending upon the stage of decomposition and the temperature at which it took place. I will not stop to describe the poisonous effects of these products' on the system. For that I must refer you to Professor Brieger's publications or to Dr A. M. Brown's treatise on the animal alkaloids. The point of interest is that they are developed during the process of putrefaction in which bacilli take an active part; and probably it is from the development of these poisons that the effects on the animal system are produced when certain of the micro-organisms gain an entrance into it. It is to be observed, that these poisons are developed by the action of bacilli on dead or effete animal matter; not necessarily on living tissue; and it might be suggested therefore that if they are produced from living tissues by the microorganisms, this can only take place when the tissue has lost its so-called vitality or when there is a departure in the tissue from the normal condition which constitutes health. But this will liardly apply to such a disorder as splenic fever, or even to tuberculosis in guinea-pigs, \&c., in which cases we have very clear evidence that the introduction of the pure cultivated microorganism into healthy animals will produce the disease. This at once suggests the question, Can the apparently innocuous or non-pathogenic bacteria be so cultivated outside the body as to develope an intense virulence and become pathogenicendowed, that is, with the power of growing and multiplying within a living animal? To this I will briefly refer later on.

Now, not only has it been demonstrated that certain poisons or ptomaines can be derived from dead putrefying animal sub- 
stances, but, moreover it has been shown by Gantier that certain alkaloids which be terms leucomaines, having poisonous propertios, are formed within the living organism and independently of the action of bacteria - waste or effete débris-by the accumulation of which in the system the vital processes are arrested. As examples of these he gives betain, guanin, xanthin, kreatinin drc. The accumulation of these substances in the system is prevented either by their destruction by oxidation, or by their elimination through the agency of the kidneys and liver. That products are formed in the living body which, if not eliminated, produce poisonous effects is well shown in cases, for example, of uræmia, gout or diabetes. The majority of observers arc of opinion that uremia is not solely due to the effect of an excess of urea or of ammonium carbonate in the blood, but to the poisonous action, in addition, of such substances as kreatin, kreatinin and other extractives or waste materials which have accumulated in the system from defective excretion by the kidneys. In gout we have uric acid exerting its poisonous effects on the nervons centres, and modifying the nutrition of parts of the body. In diabetes we have not only in some cases the formation of glucose taking place in the system, even when saccharine and starchy foods are withheld, but we have also evidence of some abnormal molecular change in the constitution of the tissnes, as shown by the marked tendency to carbuncle and to tuberculosis of the lungs. As the disease advances we have symptoms of drowsiness showing themselves, the result of some abnormal product in the blood acting on the nervous system; later on acetone appears in the urinc, and in general, not long after this stage has been reached death takes place. In the Croonian lectures for $1886 \mathrm{I}$ endeavoured to show that there were grounds for regarding living albuminous compounds as made 
up of certain cyan-alcohols united to a benzene nucleus-or in other words by combining hydrocyanic acid with a compound belonging to the benzene group and with the five aldehydes-methylic, ethylic, propionic, butyric and valeric-a compound would be formed having the same ultimate composition as albumen; and also that a considerable number of the substances such as glycocoll, lactic acid, leucine \&c. which are obtained from albuminous substances, could be prepared in the laboratory artificially from these cyan-alcohols. Assuming such a constitution for albumen, I indicated how, if the force, vital or other, which holds together these molecules forming living tissue, were modified or lessened, so that the molecules instead of undergoing the normal changes fall asunder and are partially oxidised, such substances would be produced as glucose from methylic cyan-alcohol, lactic acid and para-aldehyde from the next in the series, and oxybutyric acid and acetone from a third. I refer to this here, because the same assumption as to the constitution of albuminous material helps to explain the origin and formation of Brieger's ptomaines. From the lowest cyan-alcohol in the series $\mathrm{CH}_{2}\left\{\begin{array}{l}\mathrm{OH} \\ \mathrm{CN},\end{array}\right.$ glycocoll $\mathrm{CH}_{2}\left\{\begin{array}{l}\mathrm{NH}_{2} \\ \mathrm{COOH}\end{array}\right.$ should be obtained, which under certain conditions splits up into carbonic acid and methylamine $\mathrm{NH}_{2}\left(\mathrm{CH}_{3}\right)$. This methylamine may under certain circumstances form dimethylamine $\mathrm{NH}\left(\mathrm{CH}_{3}\right)_{2}$ and trimethylamine $\mathrm{N}\left(\mathrm{CH}_{3}\right)_{3}$, the two substances into which neuridin (the alkaloid which is the first to be separated from putrefying meat) can be decomposed. The following equation then would represent the origin of neuridin :-

$$
\underset{\text { glycocoll }}{5 \mathrm{CH}_{2}\left(\mathrm{NH}_{2}\right) \mathrm{COOH}}=\underset{\text { neuridin. }}{\mathrm{C}_{5} \mathrm{H}_{14} \mathrm{~N}_{2}}+5 \mathrm{CO}_{2}+3 \mathrm{NH}_{3}+\mathrm{H}_{2}
$$


If now we take trimethylamine and combine it with the next cyan-alcohol in the series, the ethylic, cholin should be the result$\mathrm{N}\left(\mathrm{OH}_{3}\right)_{3}+\left.\mathrm{C}_{2} \mathrm{H}_{4}\right|_{\mathrm{CN}} ^{\mathrm{OH}}+\mathrm{H}_{2} \mathrm{O}=\left.\mathrm{C}_{2} \mathrm{H}_{4}\right|_{\substack{\mathrm{N}\left(\mathrm{CH}_{3}\right)_{3} \mathrm{OH} \\ \text { trimethylamine ethylic cyan-alcohol }}} ^{\mathrm{OH}}+\mathrm{HCN}$ for cholin has been formed synthetically in the laboratory by heating ethylene chlorhydrin $\mathrm{C}_{2} \mathrm{H}_{4}\left\{\begin{array}{l}\mathrm{OH} \\ \mathrm{Cl}\end{array}\right.$ with trimethylamine, and the same reaction should hold good for the cyan-hydrin or cyan-alcohol.

Neurin differs from cholin by $\mathrm{H}_{2} \mathrm{O}$, and the former can be obtained by heating cholin with hydriodic acid and then acting upon it with moist silver oxide :-

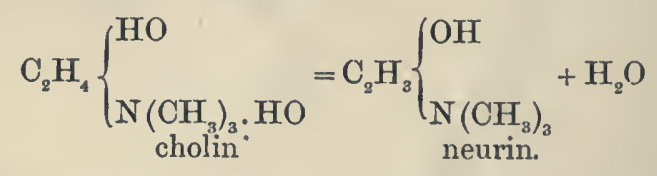

By oxidising cholin (by gently heating its hydrochloride or platino-chloride with strong nitric acid) we obtain muscarine :-

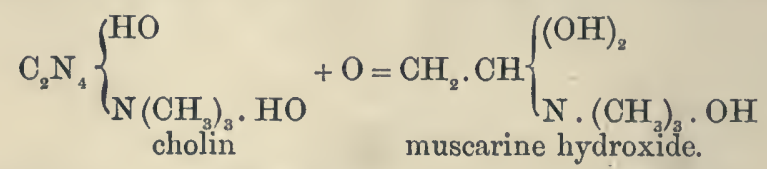

Oxidised in a different fashion cholin is converted into betain, the alkaloid of beet root:-

$$
\mathrm{C}_{2} \mathrm{H}_{4}\left\{\begin{array}{c}
\mathrm{HO} \\
\underset{\text { cholin }}{\mathrm{N}\left(\mathrm{CH}_{3}\right)_{3} \mathrm{HOO}}
\end{array}+\mathrm{O}=\mathrm{CH}_{2}\left\{\begin{array}{c}
\underset{\mathrm{N}\left(\mathrm{CH}_{3}\right)_{3} \mathrm{O}}{\text { betain, }} \\
\mathrm{CO}
\end{array}+\mathrm{H}_{2} \mathrm{O}\right.\right.
$$

a substance which has also been found, by Liebreich, in the human urine. 
Such facts as these lend some support to the view which I have advanced as to the constitution of albumen, and I mention them here in order again to call the attention of those interested in chemical physiology to the close relationship which exists between these compounds of prussic acid with the varions aldehydes, or the cyan-alcohols, and the different substances which can be extracted from albuminous tissues.

Let me now return from this digression.

From the data which I have placed before you, I wish to draw the inference that in the living animal organisms, owing to slight departures from the normal nutrition of parts, arising probably through nervous agency-the trophic nerves-various substances such as extractives or alkaloids, will be produced, which if not eliminated or neutralised, will lead to pathological changes in the system, absolutely and entirely independently of any bacterial action.

As an illustration I would refer to the pyrexia or fever which, even in healthy individuals, may follow over exertion or excessive fatigue, and which is still more readily developed in convalescents or in persons who are not very strong. Sir William Aitkin has directed special attention to this condition "which is constantly seen in all forms of physical overtaxation or over exertion, as in a prolonged march or by excessive drill, especially in young and adolescent soldiers" - and he refers to the investigations made by Professor Angelo Mosso of Turin on the physiology of fatigue as developed in the soldiers of the Italian army and the pathological manifestations which accompany it. "Fatigue carried beyond the moderate stage, at which it is decidedly beneficial, subjects the blood to a decomposing process through the infiltration into it of substances which act as poisons-substances which when 
injected into the circulation of healthy animals, induce malaise and all the signs of excessire exhaustion."

In convalescence from disease, too, how readily does the evening temperature rise after any slight physical exertion; and at the commencement of typhoid fever perhaps nothing tends to intensify the severity of the attack so much as physical fatigue. It would seem in this case as if the soil for the cultivation of the fever germ was materially euriched by the products of disintegration.

In "fatigue fever" these products are formed more ripidly than they can be eliminated or neutralised. With rest the febrile condition soon passes off, if the individual is otherwise healthy. Now it appears to be the function of certain glands besides the liver and kidneys, to get rid of the poisonous products resulting from the disintegration of the tissues, either by nentralising or decomposing them or otherwise. If the action of the glands is checked or modified either by disease or by their removal, the poisonous material soon begins to exert its specific effect on the system. We have recently been taught that following upon disease or removal of the thyroid gland the condition known as Myxœdema, with all its attendant phenomena, arises. Again in disease of the suprarenal capsules "effete pigments and effete proteids circulate in the blood; the former or their incomplete metabolites, producing pigmentation of skin and mucous membrane, and appearing often in the urine as urohæmatoporphyrin; the latter producing toxic effects, and leading to further deterioration of the blood with its consequences " (McMunn). If, then, from any cause due to glandular, nervous, or other derangement in the system, these poisonous substances are developed or not eliminated they will alter the 
composition and constitution of the blood; the white corpuscles may be destroyed, or their movements enfeebled, and, by any such changes, the blood, which previously could resist the attacks of the various parasitic micro-organisms, is so modified as to render it a suitable soil in which these organisms may develope and thrive. This view is confirmed by the experiments of Rossbach and Rosenberger, who found that when papain or sterilised septic blood was injected into the ressels, micrococci developed in the blood with extraordinary rapidity. The blood, that is to say, was so modified in character that the micrococci which could gain no entrance previous to the injection of papain, afterwards found a congenial soil for their development.

We may take another illustration from the process of fermentation. By fermentation sugar can be converted into carbonic acid and alcohol; but a pure saccharine solntion does not ferment on the addition of a small quantity of fungi or bacteria in a.pure state. Some nitrogenous material must be added as well, to act as food to the organisms, and then the transformation into carbonic acid and alcohol commences.

That it is only in particular conditions of a tissue, or at special times in its growth, that it furnishes suitable soil for the growth of the bacilli is shown by the following illustration from the vegetable world, furnished by de Bary :-

"The common garden-cress Lepidium sativum, is often attacked by a parasitic fungus of comparatively large size, Cystopus candidus. In consequence of this it shows considerable degeneration, swellings, curvatures of the stem, and often also of the fruits, and on these parts and on the leaves white spots and pustules subsequently turning to dust, which are formed by the sporogenous organs of the Cystopus, and give the entire pheno- 
menon the name of the white rust in cress. This is a case of disease, and so striking that every one notices it at once with the naked eye. Now we find in a bed of cress at about flowering time a certain number of rusty plants, two for example or twenty. They are in the middle of the other hundred or thousand plants, and these are healthy and free from the fungus and continue so till the period of vegetation is at an end. This is the case, though the Cystopus forms countless spores in the white rust-pustules, and the spores are dispersed as dust and are at once capable of germination, finding the necessary conditions for their further development in the bed of cress, and are the instruments by which the white rust-disease is eminently infectious. Nevertheless those hundred or thousand plants are not infected. All that has been hitherto said is strictly correct, and if we limit our view to this, we shall see in the phenomena which have been described a conspicuous case of individual difference in predisposition: a case too perhaps, if we judge hastily, of sickly predisposition in the plants attacked, for they do become sick and the others do not. And yet this is not the true account of the matter. Every bealthy cressplant is equally liable to the attacks of the Cystopus and to the rust-disease which it canses, only the liability is confined to a certain stage of the development, and ceases once for all when that stage is past. The germinating cress-plant in effect, first unfolds two small three-lobed leaves, the seed-leaves or cotyledons. When it has grown a little further and formed more foliage-leaves, the cotyledons wither and drop off. It appears then, that the germ-tubes of the fungus of white rust find their way into all the cotyledons and are able to develope there, and if this development has once begun, the fungus establishes 
itself at once in the tissue into which it has penetrated, and grows on in and with the growing plant, and produces the disease. The germ-tubes of Cystopus may indeed make their way for a short distance into all the other parts of the plant, but are unable to establish themselves inside it and continue their development. The plant is for the future safe from the attacks of the parasite as soon as the cotyledons have fallen off. The two or the twenty rusted plants in the bed are the ones in which the fungus attacked the cotyledons in good time; if it had attacked the thousand others in equally good time, all would have been rusted. They continued healthy, because they were not infected in the stage in which they were open to infection, that is, predisposed."

We may take another example from the human subject. Ringworm of the scalp due to the fungus Tricophyton tonsurans is not infrequently seen in children under 16 years of age, but after that age, though the fungus may affect other parts of the body, the scalp is generally free from it. Some change has taken place in the tissue there, which makes it less suitable for the growth of the parasite.

Now may not the function of the glands to which $I$ have just now alluded, viz. that of destroying or neutralising effete or toxic products formed in the system, have some bearing upon the development of tuberculosis? Thirty years ago it was suggested by Buhl that in the human subject acute miliary tuberculosis was due to the absorption into the blood of caseous matters from various sources. "It afterwards became the fashion to regard tubercle as always a secondary product the origin of which was sought for in 'caseous foci' of which the formation was supposed to precede, in all cases, the development of tuberculous lesions... The acute 
tuberculosis of children was traced back in a large number of instances to a simple intestinal or bronclial catarrh; this was supposed to lead first to swelling of the corresponding abdominal or thoracic lymph glands, and then to their caseation; and when once caseation had commenced the conditions for the development of tubercle were assumed to be present."

But, says Dr Hilton Fagge, whom I have just quoted, "Nothing is more certain than that in man, the inspissated pus of a common abscess, or the caseous matter of an atheromatous artery, or of a degenerating new growth or gumma, does not produce tuberculosis." We may neglect then the consideration of these caseous glands as "caseous foci" and yet their existence antecedent to or associated with tuberculosis is so general, that to the mind of the practical physician it would seem as if there must be some distinct relationship, as to cause and effect, between them.

\section{May I venture to offer an interpretation of the fact?}

Suppose that in an individual we have such a condition of the glands either inherited or acquired, such a "vulnerability" so to speak, that from more or less slight irritation of the mucous membrane of the throat, of the lungs, or of the intestines, the glands in connection with those parts become enlarged and inflamed and, instead of recovering, become cuseous, these organs then would no longer be able to perform their function, whatever that function may be; and if it be that of modifying or destroying the effete material coming to them as the result of normal changes in the mucous membrane, this effete material must pass on into the circulation generally, and produce its noxious effects-lessen, it may be, the vitality of the white blood-corpuscles, or the epithelial or endothelial cells, or so modify the condition of the blood, that the tubercle bacillus finds a suitable soil in which to 
develope and flourish. Or it may be that these poisonous substances act specially as irritants of epithelial structure, causing an overgrowth of epithelial cells, just as we know will be the result when any other irritant is applied to these tissues; and so the soil is prepared for the lodgment of the bacillus. The human body in the normal state of things may be able to destroy the bacillus tuberculosis, just as the white corpuscles of the frog in Metschnikoff's experiment could destroy the bacillus anthracis, but not when placed in abnormal conditions.

In connection with this view of the matter, it is significant to find in the case of animals inoculated with tubercle that the lymph glands in the neighbourhood of the inoculation become enlarged and caseous, and this precedes general tuberculosis by a longer or a shorter time.

Nor would I maintain that the loss of function caused by the swelling and caseation of the various glands was the only way in which the tissue soil could be prepared for the reception of the bacilli. If, as I urge, tissue in a state of decay is suitable, so then I would suggest that imperfectly formed tissue would furnish equally suitable food for these parasites. Such tissue as would result from living in a olose atmosphere with poor and insufficient food and insufficient exercise.

We could not imagine any conditions better calculated than these I have just mentioned to lower the activity or vitality of the epithelial cells of the pulmonary alveoli, or to interfere with the perfect organisation of the tissues generally, or to conduce more effectively to the accumulation of waste or effete material in the circulation, or to impede generally the action of the glandular structures, whereby these waste products should be rendered innocuous; and no wonder that under these conditions the 
tubercle bacillus finds a congenial home in which it spreads and thrives and multiplies.

Again, the condition often seen in some parts antecedent to the formation of tubercles in the human system indicates that there is often some structural change before the bacilli take possession of the part, and "that their appearance on the scene is subsequent to the damage of which they are in fact the pathological consequences." Not infrequently, in cases of acute tuberculosis of other organs we find an affection of the membranes of the brain presenting all the characters of simple inflammation, no tubercles being discoverable. And in the lungs the first stage of the morbid process is of a similar character, namely the filling of the alveoli with epithelial cells, or in other words a "catarrhal pneumonia." And according to the vitality of these epithelial cells will be the changes produced in them by the bacilli. Some of the cells possessing greater vitality will, when attacked by the bacilli, go on increasing or coalescing, and so, in some way or other, the formation of the so-called "giant cells" takes place, which at one time were regarded as the typical elements of tubercle, and the remarkable phagocyte property of which has been recently shown by Metschnikoff to be something more than a theory. If the cells are of a weaker nature they quickly die and undergo degeneration, and become caseous.

And, once again, it may be suggested that when the bacilli have gained a footing in this effete or enfecbled tissue, whilst absorbing from it the constituents of their own protoplasm, they may give rise to, or secrete, poisonous products or ferments, capable of still further destroying or weakening the surrounding tissue or cellular elements and so obtain fresh food on which they can thrive. In this way, to use Dr Sanderson's words: 
"germs are not so much 'mischief makers' as mischief spreaders, that is to say that although an inflammation may come into existence without their aid, their presence communicates to it after it has come into existence the power of reproducing itself in previouslý healthy tissues whether by extension or dissemination."

Sometimes, however, even though the tubercle bacilli establish themselves in the tissue the epithelial cells may become strong enough to resist their further invasion and destroy them. The bacilli disappear and a "fibrous tubercle" containing giant cells but no bacilli is left behind as evidence of the fight which has taken place.

And does not this fact furnish us with our most important lesson? viz. that in the prevention and treatment of consumptive mischief our aim must be not so much to fight against the bacillus as to strengthen the parts attacked. To improve, that is, the condition of the blood and of the cellular elements by suitable dietetic, hygienic and medicinal means. And is not this in accordance with sound practical experience? That the tubercle bacillus will communicate the disease under ordinary circumstances to healthy individuals cannot for one moment be admitted. The statistics compiled by Drs Cotton and Theodore Williams and Mr Edwards from the records of the Brompton Hospital relating to several hundreds of individuals, subjected more or less to contact and association with consumptive patients for three months and upwards, directly negative any idea of consumption being, in the ordinary sense of the word, an infectious disease. And therefore if a healthy human.system can resist the invasion of the bacillus, surely the common sense view of preventing its invasion, or arresting its progress, must be to adopt such measures as will tend to the development of healthy tissue. That the internal administration 
of cod-liver oil is of great service generally in the treatment of Phthisis few I think will deny, and the same may be said of the free use of butter as an article of diet; the latter sometimes even appears to answer better than the cod oil, and is certainly more willingly taken. But what possible effect can oil and butter have on bacilli? Indeed I fear that the discovery of the tubercle bacillus has not proved in some respects to be an unmixed benefit, and that the result of treating patients in various ways by antiseptic remedies, has been that the patient, and not the bacillus, has succumbed.

Lastly, there is one important point to refer to in connection with these micro-organisms. We are surrounded on all sides with certain forms of them which under ordinary circumstances produce no injurious effects on the human frame, living only as saprophytes on dead animal or vegetable matter. Can these harmless organisms under any mode of cultivation acquire virulent or poisonous properties enabling them to attack living animal matter? Can the common bacillus of hay infusion, the bacillus subtilis be transformed into the bacillus anthracis? Or putting the question more generally can a specific disease arise de novo? Pathologists and bacteriologists differ strongly on this point. Buchner says that the transmutation of the hay bacillus into the bacillus anthracis does take place. Koch and Klein say it is impossible. All admit that the bacillus anthracis, if cultivated outside the human body, artificially, at a certain temperature, can have its properties so modified that it ceases to be poisonous, and after six weeks' attenuation can be injected into the blood of a living animal without producing any injurious effects : rabbits resist the injurious effects at an early stage of attenuation, guinea-pigs at a later stage, while it is only after the parasite has been cultivated 
for a period somewhat less than six weeks that mice seem to be impervious to its attacks. But how it is that this attenuation takes place-whether it is due to the effect of heat alone or to the effect of oxygen-bacteriologists are by no means agreed. Further it has been shown that when the attenuation of the bacillus has been brought about in a certain way (by the addition for instance of carbolic acid or potassium bichromate to the cultivation) its virulence is not regained when cultivated in fresh material at the ordinary temperature. But, attenuated in a different fashion, it does regain its virulence under those conditions. Again the virulence of a parasitic organism is materially altered according to the animal through which it has been transmitted. "In the course of Pasteur's interesting researches on swine plague he found that pigeons inoculated with the virus of swine plague died in six or eight days after suffering in the first instance from symptoms like those of fowl cholera. If the disease is transmitted from pigeon to pigeon, the organism after a time acts more violently, and the animal dies sooner. If, now, pigs are inoculated from these pigeons, death occurs more quickly than when inoculated from a pig, the organism having become more virulent. With the rabbit the converse is the case. The virus kills rabbits, but if it is passed through a series of rabbits it is no longer able to kill pigs" (Watson Cheyne).

Now, if this is the case, if the virulence of parasitic or pathogenic organisms can be thus modified, it seems incredible that organisms of similar structure, though apparently harmless saprophytes, cannot be cultivated in some way or other so as to become pathogenic. And when the bacteriologists tell us that it is impossible, that only means, I suppose, that they have not yet discovered the way. Specific diseases and pathogenic bacteria

L. 


\section{4}

can hardly have existed from the founclation of the world; they must each have had their period of development, and what has developed through one period of time, may be developed again under similar circumstances. This may require a combination of circumstances acting simultaneously. Each circumstance separately may be in frequent action, but the necessary combination may present itself very rarely. A certain temperature and a special pabulum-a product perhaps of a certain stage of putrefaction-may be the first requisites to develope the pathogenic power of the hacterium; it may then require a special condition of the living animal organism, a lowered vitality, or an enfeebled state of health-the result perhaps of the same conditions of air, soil and temperature \&c. which have called forth the power of the parasite-before it can find an entrance; and possibly after that its transmission through different species of animals may be necessary before it aequires destructive virulence, and is able, like the bacillus anthracis, to attack sound and healthy tissue. Instances are not rare of vegetable cells possessing poisonous properties at one time and not at another. Nägeli has called attention to one of the most striking which is thus described by de Bary:- "The bitter almond tree is poisonous from the amount of amygdalin it contains, though it is not very dangerous to human beings; the swect almond contains no amygdalin and is not poisonous. The sweet almond tree does not differ speeifically from the bitter; a tree with bitter seeds may be produced from a sweet seed; bitter and sweet seeds may even be borne on the same tree in flowers and fruits not morphologically distinguishable from each other." What the origin or cause of this difference is, has not yet been discovered, and no explanation can as yet be offered; 
but the fact will help us to understand that cells may be developed by these micro-organisms capable of producing very diverse effects upon the system; and $I$ incline therefore to the view that, probably from the simple neglect of ordinary sanitary measures, innocuous micro-organisms may become virulent and that diseases may arise de novo.

I have however detained you already too long with these speculations, and will not proceed further with them, tempting and important though the subject may be. One thing is clear and certain; there is very distinct evidence showing a relation between bacteria and certain diseases both in man and animals; but what the exact modus operandi is in the production of the disease can only be learned from further investigation, and additional study nay throw a very different light on the relationship of these organisms to the respective maladies from that in which it may now be regarded. Whether this will be so or not, it seems to me, that with increasing knowledge of the chemical changes in the blood and in the tissues, we are on the threshold of most important discoveries, and of a very marked advance in the science of medicine. That physiologists are recognising in a greater degree than formerly the importance-nay, the absolute necessity - of further acquaintance with chemical physiology, is shown in a marked way, by the appearance of such works as those of Gamgee and Charles, and especially that most recent and most valuable one of $M^{\circ}$ Kendrick. Perhaps by further investigations into the chemical changes produced by bacilli, the constitution of the proteid molecule, complex as its nature is now regarded, may be unravelled and its propertios better understood; we may be able to discover, possibly, what poison it is which the bacillus secretes, or low it is formed, or 
from what constituent of the proteil molecule it is derived. The other constituents of the molecule may perhaps furnish the antidote, or a poison antagonistic to that produced by the bacillus; for we know that poisons are antagonistic to each other-atropin and muscarin for example. We may even hope to find that the action and growth of the bacilli may be inhibited by certain substances, and then by injecting these substances into the blood, disease may be prevented, or if disease exists it may be arrested or cured. Is there not then, in this direction, much that should attract you and in Harvey's words "encourage you to search out the secrets of nature"? The changes seem so minute and inscrutable, sometimes so transitory, that amidst difficulties and clisappointments we may often be discouraged and inclined to abandon the investigations. So it was with Harvey-"I found the task so truly arduous, so full of difficulties, that I was almost tempted to think with Fracastorius, that the motion of the heart was only to be comprehended by God.......At length by using greater and daily diligence......I thought that $I$ had attained the truth....... and that I had discovered what I so much desired, both the motion and the use of the heart and arteries." Reverently, earnestly and hopefully he continued his work, and he succeeded. Lct us follow in his footsteps, gathering up the facts, and with minds educated and trained to reason upon the facts, let us try to penetrate further into nature's mysteries; thus may we be enabled to do God's work in the world, preventing and healing all manner of diseases, and so promote the happiness and welfare of mankind. Ono, whose memory is reverenced by all here, Dr Parkes, wrote: "In the scheme of Providence it may not. be meant that man shall be healthy. Diseases of mind and body may be the cross he has to bear; or it may be the evil against which he has to struggle, 
and whose shackles he has finally to unloose. The last disease will disappear, we may believe, only when man is perfect; and as in the presence of the Saviour all disease was healed, so, before perfect virtue, sorrow and suffering shall fade away. Whether the world is ever to see such a consummation no man can say; but as ages roll on, hope does in some measure grow. In the midst of all our weaknesses, and all our many errors, we are certainly gaining knowledge, and that knowledge tells us, in no doubtful terms, that the fate of man is in his own hands." Let us hopefully strive to increase that knowledge and so help, each one, to hasten on the time, far distant though it yet appears, when the last disease will disappear and man be perfect; when "there shall be no more death, neither sorrow, nor crying, neitlier shall there be any more pain : for the former things are passed away." 

By the same Author.

\section{THE CROONIAN LECTURES FOR 1886. Price $3 s .6 d$.}

\section{ON SOME POINTS IN THE PATHOLOGY OF} RHEUMATISII, GOUT, AND DIABETES; the Croonian Lectures for 1886, delivered at the Royal College of Physicians, London.

"Nothing could be clearer or more precise than Dr Latham's exposition of the difficult problems with which he essays to grapple....Further research will demonstrate how far the author's views are scientifically sound; but in any case his work is a most praiseworthy and valuable contribution to modern medicine, and ought to be read and pondered by every physician who is interested in the elucidation of the vast problems of which it treats." -Saturday Review.

"We believe their perusal will repay every thoughtful practitioner of medicine, for Dr Latham has, we think, succeeded in the endeavour to indicate some of the changes in the nervous system, the blood, and the tissues which may take place in diabetes, rheumatism, and gout. Hc has, further, brought together a number of facts, as he says himself, and drawn certain inferences from them, which, whether right or wrong, will certainly help to a better understanding of the diseases in question."-British Medical Journal.

“The arguments in support of Dr Latham's views afforded by appropriate treatment of rheumatism, gout, and diabetes by salicylic and benzoic acids and colchicum are not the least interesting part of the Croonian Lectures."The Lancet.

"Dr Latham has made a valuable addition to the literature of the diseases which he discusses. Whatever may be the opinion as to his theory, there can be no two opinions as to the skill and ability with which he has collected and stated his facts and drawn his conclusions."-Scotsman.

"These lectures will serve a most important purpose by bringing to a focus, as it were, not only the author's own investigations, but the work of his contemporaries, and by causing interest in a field of investigation which is only now opening up to workers at physiological chemistry." -Edinburgh Medical Journal.

CANBRIDGE : DEIGHTON, BELL, \& CO. LONDON: GEORGE BELL \& SONS. 

2. 

$-$

(1)

(1)

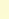

(1)

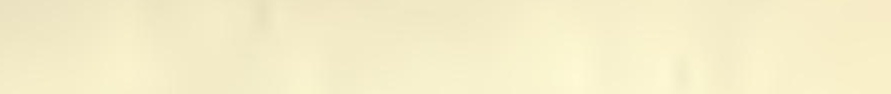



QR

58

L3

\section{Biological}

\& Medieal

\section{Latham, P.I.}

The Harveian oration

\section{PLEASE DO NOT REMOVE}

CARDS OR SLIPS FROM THIS POCKET

\section{UNIVERSTTY OF TORONTO LIBRARY}


